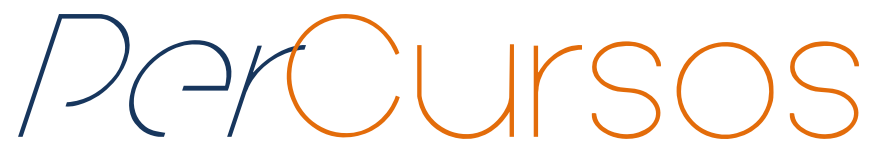

\title{
"Quem possui a terra, possui o homem": abolicionismo e democracia rural nas ideias agrárias de André Rebouças
}

\begin{abstract}
Resumo
No final do século XIX ampliam-se os debates acerca da escravidão e da ocupação de terras no Brasil. Muitos indivíduos e grupos defendiam a colonização e a imigração como forma de resolver a questão do trabalho nas lavouras. Nesse contexto, o engenheiro e abolicionista André Rebouças criticava amplamente a forma como, ao mesmo tempo em que se concedia uma série de direitos aos trabalhadores estrangeiros, desprezava-se o trabalhador nacional. Esse se tornou um elemento importante em seus escritos, uma vez que seus projetos de reforma agrária incluíram tanto trabalhadores europeus, quanto brasileiros. Este artigo busca evidenciar suas principais ideias sobre o abolicionismo e reforma agrária e sua participação nos debates e projetos que deveriam provocar uma verdadeira reforma nacional. Para Rebouças, a superação do atraso do país não se daria com a mera modificação de vínculos jurídicos, antes era necessário mais: democracia rural, fim dos latifúndios, a criação do imposto territorial, o parcelamento da terra, loteamento das terras devolutas e colonização.
\end{abstract}

Palavras-chave: André Rebouças. Democracia rural. Reforma agrária.

\author{
Angela Bernadete Lima \\ Doutora em História pela \\ Universidade Federal de Santa \\ Catarina - UFSC. Membro do \\ Laboratório de Imigração, \\ Migração e História Ambiental - \\ LABIMHA - UFSC. \\ Brasil \\ angela_ufsc@hotmail.com
}

\footnotetext{
Para citar este artigo:

LIMA, Angela B. "Quem possui a terra, possui o homem": abolicionismo e democracia rural nas ideias agrárias de André Rebouças. Revista PerCursos, Florianópolis, v. 20, n.43, p. 295 - 314, maio/ago. 2019.
}

DOI: $10.5965 / 1984724620432019295$

http://dx.doi.org/10.5965/1984724620432019295 


\title{
"The one who owns the land, owns the man": abolitionism and rural democracy in the agrarian ideas of André Rebouças
}

\begin{abstract}
At the end of the nineteenth century there was an expansion of debates about slavery and land occupation in Brazil. Many individuals and groups advocated colonization and immigration as a way to address the issue of farm labor. In this context, the engineer and abolitionist André Rebouças widely criticized the way in which, while granting a series of rights to foreign workers, the national worker was despised. This became an important element in his writings, since his agrarian reform projects included both European and Brazilian workers. This article seeks to highlight its main ideas about the abolitionism and agrarian reform and its participation in the debates and projects that should provoke a true national reform. For Rebouças, overcoming the backwardness of the country would not be achieved by merely changing legal ties, but it was necessary to do more: rural democracy, the end of large country estate, the creation of a territorial tax, land subdivision, vacant land allotment and colonization.
\end{abstract}

Keywords: André Rebouças. Rural democracy. Land reform. 


\section{Aspectos gerais do contexto histórico: escravidão e imigração}

Na segunda metade do século XIX, o regime escravocrata de trabalho e o modelo de colonização das terras do Brasil configuravam-se como um grande obstáculo para as intenções imigratórias cada vez mais crescentes. Ao lado disso, existia uma ampla discussão sobre da criação de um mercado de trabalho livre mas, para tanto, fazia-se necessário estimular a própria criação, ou recuperação, da ideia de trabalho. Inseridos num mesmo contexto, o trabalho escravo e o trabalho livre chamam a atenção dos historiadores para os problemas decorrentes da lógica econômica operante naquele momento, a do latifúndio. Essas grandes propriedades de terra, naquele final de século XIX, estavam sendo ameaçadas pela iminência do fim do trabalho em regime escravo e passam a depender cada vez mais da vinda de trabalhadores estrangeiros para realizar as atividades na agricultura e pecuária.

Temos, portanto, mais um dos momentos em que surgiram amplas discussões acerca dos pilares que sustentavam a economia do país e as mudanças que necessitavam ser implantadas. Com isso, muitos dos indivíduos da elite social e política ampliam a defesa e desenvolvem argumentações diversas acerca da inserção dos estrangeiros para dar fim ao malogro da escravidão, ao atraso técnico na produção agrícola e, de maneira mais utópica, ao latifúndio. Portanto, os fatores conexos ao chamado "atraso" do Brasil com relação às nações europeias serviram de pano de fundo para as discussões colocadas pelos indivíduos envolvidos nesse contexto no final do século XIX.

Os discursos, permeados de interesses, enfatizavam a necessidade de criação de uma nação moderna, livre do trabalho escravo e com uma nova estrutura agrária. Sabemos que muitos são os estudos que buscam esclarecer as questões postas no final do século XIX, especialmente no que se refere à abolição do trabalho escravo e da forma como a política foi conduzida para que fosse possível a proclamação do regime republicano, assim como os estudos sobre as ideias e indivíduos neles envolvidos.

A maior parte das questões problematizadas partiam da premissa de que uma nova configuração social, baseada no trabalho livre deveria ser formada, preferencialmente com trabalhadores estrangeiros. No entanto, na opinião dos 
latifundiários, essa transição, caso viesse mesmo a se concretizar, deveria ocorrer sem que fossem postas em prática alterações na estrutura agrária e na produção. Almejava-se, segundo esses indivíduos, uma modernização que não alterasse a correlação de forças, em que a elite proprietária permaneceria intocada, assim como as suas propriedades.

A resolução de todas essas questões não seria simples, ao contrário, resultaria de todo um processo bastante complexo e que parecia não definir que direção deveria ser seguida. Mas, enfim houve consenso, estimular a vinda do imigrante europeu. Entretanto, as primeiras experiências realizadas com imigrantes na primeira metade do século XIX, no sistema de parceria estabelecido principalmente nas fazendas de café paulistas e fluminenses, não apresentaram os resultados esperados, e isso significa dizer que a escolha pelo imigrante igualmente tinha seus entraves.

A colonização baseada no regime da pequena propriedade agrícola já vinha sendo discutida e algumas tentativas de colocá-la em prática datam do início do século XIX. Nesse momento, quando a estrutura social correspondia economicamente a monocultura da cana-de-açúcar, alguns homens da política advertiam sobre a necessidade de se formar uma camada média, especialmente com o início da era imperial com a produção agrícola cada vez mais baseada no café.

Algumas colocações davam conta de que, do mesmo modo como a questão do trabalho na lavoura apresentava problemas, o atraso técnico da agricultura nacional naquele momento precisava ser vencido, e os desejos de mudança suscitaram uma verdadeira amplitude das discussões acerca de mudanças nas lavouras. Um exemplo foram os Congressos Agrícolas que tiveram lugar no ano de 1878, e que são também um retrato do reformismo que tomou lugar no final do século XIX. Dentre tantos temas, a incondicional defesa do europeu, preferencialmente provenientes do norte da Europa, como melhor solução para as questões de braços ao trabalho agrícola trazia consigo ainda a expectativa de progresso em termos sociais, étnicos, das técnicas empregadas na lavoura e também na diversificação do cultivo.

De igual modo, discutia-se a questão dos direitos e de cidadania, sendo este um aspecto bastante abordado pelos autores naquele momento, e que ganhava importância 
especialmente nos escritos dos abolicionistas, como foi o caso de André Rebouças e Joaquim Nabuco. Em seus textos, averígua-se a amplitude que tal conceito possuía. Tratava-se, pois, da universalização de direitos civis e sociais a todos - brancos, imigrantes, indígenas ou libertos. Alguns defenderam fortemente a extensão do voto, as clássicas liberdades políticas e o acesso à propriedade da terra - a base da própria liberdade, de acordo com André Rebouças.

Tomado por tais ideias e envolvido com projetos e ações direcionadas às mudanças desejadas, André Rebouças buscou alertar para a necessidade de uma efetiva integração dos ex-escravos. Para tanto, redigiu escritos nos quais objetivava esclarecer essa necessidade, buscando uma justiça social com aqueles que sofriam da total exploração. Em 1890, escreve a frase "quem possui a terra, possui o homem", expondo os problemas decorrentes da concentração de terras em uma nação dependente do trabalho escravo. Para Rebouças, a prosperidade dependia justamente da alteração da estrutura fundiária, com a real implementação de uma reforma agrária que deveria ocorrer em conjunto com incentivos e com a adoção de tecnologias e conhecimentos que permitissem a melhoria da produção agrícola.

\section{Um abolicionista que atuava na imigração}

O engenheiro Rebouças, profundo conhecedor da realidade nacional por haver, em diversas ocasiões, viajado pelo país no exercício de suas funções de projetista, dedicou boa parte de sua vida a escrever sobre esses assuntos. O resultado de seus anseios e ideias foi uma obra significativa em que buscou detalhar o que definiu como “democracia rural”. Além disso, sempre esteve envolvido com grupos e indivíduos que buscavam de igual modo transformações na estrutura social e econômica.

Ao longo das últimas duas décadas do regime monárquico, quando o processo de desagregação da escravidão intensificou-se, paralelamente ao progressivo declínio do regime monárquico, uma série de questões são retomadas com mais intensidade, como a da substituição da mão de obra escrava pelo braço livre, o aproveitamento ou não da mão de obra nacional, a imigração e questão fundiária. Dentre os indivíduos que 
pensaram alternativas para os problemas do Brasil, alguns incluíram em suas propostas a ideia de reforma agrária e implantação da pequena propriedade rural (LIMA, 2015, p. 22).

O desejo pela democratização do espaço rural de André Rebouças foi igualmente expressado e discutido por alguns indivíduos do governo, através, por exemplo, da sugestão de se criar um imposto territorial ou, ainda, de se instituírem colônias agrícolas à margem de rios e de estradas, que beneficiariam os imigrantes, os nacionais e os libertos. As medidas propostas, em seu todo, incentivariam a formação de uma classe média rural. Dentre os grupos que buscaram implantar tais transformações, podemos destacar a Sociedade Central de Imigração, da qual Rebouças fazia parte.

Idealizada e fundada no final do século XIX, a Sociedade Central de Imigração (SCI) trazia como objetivo principal organizar e promover o aumento da imigração de europeus para desenvolver atividades agrícolas, ao mesmo tempo garantindo-lhes boas condições de deslocamento da Europa para o Brasil, sua instalação nos núcleos e trabalho. Contudo, embora a ênfase no trabalho fosse sempre importante, a intenção não era apenas angariar mão de obra qualificada, mas incentivar uma mudança na forma de ocupação das terras no Brasil. Suas propostas direcionavam-se para a alteração de algumas estruturas que podem ser consideradas como componentes de um projeto modernizador e reformador da sociedade brasileira.

A SCl, durante quase uma década de existência, buscou elaborar estratégias para atrair imigrantes através de uma intensa propaganda em duas frentes: uma interna, visando convencer os nacionais sobre as vantagens da imigração, e externa, direcionando propagandas aos governos e populações dos países alvos. As propagandas aconteciam por meio de discursos, artigos, periódicos, cartas etc. Todo esse material foi publicado no jornal mensal do grupo A Immigração, que circulou de dezembro de 1883 a abril de 1891 (LIMA, 2015, p. 23).

Em sua composição, a SCl contava com destacadas figuras do Império do Brasil, e também com o apoio do imperador Dom Pedro II. Em suas listas de membros é possível localizar os mais proeminentes nomes da política, da literatura, do comércio, das ciências e da imprensa da época. A sociedade era organizada de forma a atuar não apenas na 
Corte do Rio de Janeiro, mas buscou apoio para atuar em todo o território nacional, especialmente nas localidades mais indicadas a receberem imigrantes. Foi assim, tomando parte do projeto da $\mathrm{SCl}$ em incentivar e regulamentar a imigração e seus assuntos, que André Rebouças uniu-se ao grupo e tornou-se o seu primeiro secretário e um dos mais destacados e atuantes membros.

Originário da Bahia, tendo nascido em 13 de janeiro de 1838, e se dirigido com sua família para a Corte do Rio de Janeiro, Rebouças tornou-se um abolicionista ferrenho e um dos engenheiros mais expoentes do período. Era mulato, contudo sua família possuía uma posição respeitável na pequena burguesia brasileira. Tinha uma formação semelhante à dos demais nomes de destaque naquele contexto, com período de estudos na Europa onde entrou em contato com sua cultura e passou a admirar a seu progresso. Sua atuação foi analisada por diferentes autores, seja no quadro de um estudo sobre o movimento liberal e abolicionista, seja na caracterização do abolicionismo como um todo, ou de uma pesquisa voltada especificamente para sua trajetória. Nesse último caso, destacam-se os nomes de Joselice Jucá, Maria Alice Rezende de Carvalho, Sidney dos Santos e Andréa Pessanha, que desenvolveram estudos densos sobre Rebouças.

O engenheiro criticava amplamente a forma como, ao mesmo tempo em que se concedia uma série de direitos aos trabalhadores estrangeiros, desprezava-se o trabalhador nacional. Esse se tornou um elemento importante em seus escritos, uma vez que seus projetos de reforma agrária incluíram tanto trabalhadores europeus quanto brasileiros. Por outro lado, já naquele período, Rebouças pregava uma associação entre o povoamento e a propriedade privada; valorizava a importância do imigrante proprietário como agente de defesa, além de gerador de prosperidade para o país.

Na visão de Rebouças, a superação do atraso do país não se daria com a mera modificação de vínculos jurídicos, antes era necessário mais: democracia rural; fim dos latifúndios; criação do imposto territorial, parcelamento da terra; loteamento das terras devolutas e colonização nos eixos ferroviários. Além disso, sua proposta previa a implantação de centrais agrícolas, fazendas ou fábricas que receberiam a produção das pequenas propriedades fornecedoras de matéria-prima. Também seriam criados, sob forma cooperativa, "bancos territoriais", com debentures lançadas no mercado 
financeiro e lucros destinados ao crédito comercial para financiar a produção e implantar as técnicas mais modernas de cultivo, colheita e processamento (JUCÁ, 1988).

Além disso, Rebouças era bastante empolgado com a ideia de progresso com o mesmo vigor que defendia a implantação de projetos de educação, higiene e saneamento como necessários para o país. Para além das questões sociais, empenhou-se pessoalmente na implantação de obras e serviços de infraestrutura, principalmente nas áreas de portos e de transporte. Na década de 1870, percebe-se que o engenheiro estava mais ligado às atividades empreendedoras, que ajudariam a moldar a sua visão social, defensora do modelo do self made man, proveniente dos Estados Unidos, país que visitou em 1873, em seguida à Europa (JUCÁ, 1988, p. 31). Igualmente nos anos 1870, o engenheiro passou a escrever artigos em jornais. No final da década, com a irrupção do movimento abolicionista, Rebouças passaria a desempenhar um papel-chave, assumindo função de destaque enquanto propagandista da causa. Em 1880, o engenheiro nomeado naquele ano Professor da Escola Normal - participou da fundação, junto com Joaquim Nabuco, da Sociedade Brasileira Contra a Escravidão.

Além disso, atuou como militar na Guerra do Paraguai, tendo trabalhado posteriormente como engenheiro em diversos projetos governamentais e privados. Foi professor da Escola Politécnica, antiga Escola Militar, onde estudou e desenvolveu a atividade de escritor divulgando em jornais os seus escritos sobre economia, colonização, abolição e outros aspectos sociais. Por ser militante do movimento abolicionista, em muitos momentos enfrentou dificuldades profissionais. Preocupava-se com a abolição, com a grande propriedade e, mais diretamente, com o progresso que a resolução desses problemas poderia possibilitar ao Império do Brasil. Dentre os membros da $\mathrm{SCl}$, Rebouças revela aspectos distintos, assim como expressiva antecipação em relação ao movimento abolicionista. As suas ideias relativas à imigração são reflexo de sua oposição à escravidão e, inseridas em uma análise mais ampla da questão, pressupõem evitar a escravização do imigrante pelos donos da terra.

Como abolicionista ferrenho, Rebouças pugnou não apenas pelo fim da escravidão, mas alertava que a libertação pura e simples da população cativa, sem que tivessem acesso à terra, a oportunidades reais de trabalho e à educação, resultaria em 
uma simples substituição do cativeiro pela miséria e a marginalidade. Assim, no auge de sua luta abolicionista, Rebouças reagiu com grande veemência à pretensão de indenizar os proprietários de escravos no caso de libertação. Seus escritos também nos permitem perceber que acreditava num progresso técnico em que a preparação do trabalhador era condição fundamental para a melhoria dos métodos agrícolas. Por conta dessa visão, as suas propostas eram diferenciadas das demais, uma vez que se preocupava com o progresso e a moralização do trabalho.

Acreditava que com a abolição e a consequente desorganização do trabalho naquele contexto, se favoreceria a extinção das grandes propriedades e isso aumentaria a necessidade de um progresso técnico e da racionalização da produção. O resultado direto de tal prerrogativa seria o surgimento de uma classe média no campo. E, sobre a moralização do trabalho, direcionava intensas críticas às elites afirmando que o “parasitismo superior cria o parasitismo inferior” (REBOUÇAS, 1988, p. 13).

Após a abolição da escravatura, a preocupação e a luta de Rebouças continuaram sendo favoráveis à educação, à fragmentação do latifúndio, à imigração europeia e à valorização do trabalho. Acrescentou às suas argumentações o tema da extinção da miséria - num contexto após a Lei Áurea - que deveria atingir majoritariamente a população negra. A presença de Rebouças nos jornais, após o fim da escravidão, defendendo a continuidade de seu projeto para o Brasil, indica que as reformas sociais, para segmentos que participaram da campanha abolicionista, não deveriam parar com o 13 de maio.

As propostas que foram sistematicamente sendo colocadas em discussão por Rebouças e seus companheiros de $\mathrm{SCl}$ traziam novos elementos para as mudanças na lógica social e econômica. Uma delas foi a defesa da educação e instrução agrícola como questões fundamentais para o avanço das demais demandas. Tratava-se de preparar as "classes inferiores" para a nova configuração que o Império assumiria com a extinção do trabalho escravo. As propostas reformistas visavam obter soluções de médio e longo prazo para atender a essa nova configuração. Ao propor o favorecimento da formação de uma classe média rural e a democratização das terras com o intuito de melhorar o seu aproveitamento econômico, pensava-se, inicialmente, que essa nova ordem resultaria em 
estabilidade política. Nesse sentido, a transição do trabalho escravo para o trabalho livre não traria a tão temida desorganização social.

\section{A defesa de uma democracia rural}

Analisando a trajetória de Rebouças, podemos dizer que na década de 1870 ele já vinha chamando a atenção para muitas das questões que vieram a ser retomadas posteriormente, especialmente na década de 1880. Assim, na década anterior às suas atividades junto a $\mathrm{SCl}$, ele já apresentava ideias críticas em relação à ordem social, externando seu repúdio pela dominação política dos grandes proprietários rurais, pela estreiteza do sistema político eleitoral, pela escravidão e por uma intensa concentração fundiária.

Assim, nesse período, Rebouças orientou-se pela defesa de um determinado modelo para a sociedade, na qual o eixo de modificação estaria contido na ação dos indivíduos, baseando-se numa espécie de "economia moral" e inspirando-se no exemplo dos Estados Unidos da América. Seguindo um "liberalismo social”, Rebouças já se revelava - em artigos publicados a partir de 1874 e reunidos posteriormente no livro Agricultura Nacional -, favorável à abolição da escravidão e à fragmentação da grande propriedade. Buscou combater, segundo Pessanha (2005, p. 102), principalmente a "agricultura extensiva realizada nos latifúndios".

Rebouças buscou de todo modo evitar seguir a carreira política, mesmo que compactuasse com aquela nova geração de liberais que vinha ganhando espaço na política do Império. Sobre esse aspecto, Maria Alice Rezende de Carvalho (1998, p. 205) afirma que Rebouças seguia prerrogativas que rompiam com o liberalismo que vinha sendo praticado até aquele contexto pelos dois partidos imperiais. O seu liberalismo reconhecia o direito à liberdade como estando acima do direito à propriedade, diferenciando-se aí radicalmente do velho liberalismo dos latifundiários e donos de escravos. Ele achava, ainda, que a liberdade deveria ter por base a propriedade. Conforme Inoã Ubinati (2008, p. 33) analisou em seu trabalho, a propriedade da terra 
pelo trabalhador rural, nesse sentido, seria por ele extremamente valorizada e marcaria fortemente o teor de sua análise social.

Os seus projetos e suas inúmeras ideias voltadas para a questão agrária estão discutidos em pormenores no livro Agricultura Nacional, no qual igualmente é possível localizar as suas prerrogativas para que a terra fosse acessível para um maior número de trabalhadores rurais. De acordo com Joselice Jucá (1988, p. 119), André Rebouças pode ser considerado como um "conservador progressista". Costuma ser visto como um defensor de ideias avançadas para a época, com muitas sugestões de atualidade.

A abordagem de Rebouças acerca da problemática rural foi descrita como sendo de uma atualidade marcante, como se pode perceber pela leitura dos textos de Andréa Pessanha e de José Augusto Pádua. Muitos alertaram para o fato de, até hoje, a "subdivisão do solo", como pregavam Rebouças e outros membros da $\mathrm{SCl}$, não ter sido ainda efetivada. A proposta agrária de Rebouças inseria-se num amplo leque de reformas sociais, que incluiriam o apoio à educação, cujo acesso às camadas marginalizadas dos libertos, dos imigrantes e dos trabalhadores pobres do campo deveria ser franqueado. Alguns historiadores destacaram o evolucionismo social de Rebouças como um fator importante para se apreender suas ideias reformistas.

Constatava-se a ideia de uma superioridade da civilização ocidental, que Rebouças, fortemente impregnado de um sentimento pró Europa, parecia endossar. Dentro dessa perspectiva, as reformas sociais por ele preconizadas auxiliariam, de modo decisivo, no adiantamento da etnia africana, após séculos de escravidão e de barbárie. O acesso à propriedade rural, bem como à educação, fariam parte desse programa, em que, no final, tanto os negros como os brancos estariam no mesmo patamar. A questão agrária constituía um dos centros da visão social de Rebouças. Era um "reformador social no sentido de defender a implementação de uma reforma agrária e a eliminação do antigo sistema da posse da terra associado à escravidão" (JUCÁ, 1988, p. 12).

No entanto, quais são as características principais do que André Rebouças chamou de "Democracia Rural”? Rebouças vislumbrava o acesso à propriedade rural em termos não apenas econômicos e sociais, mas também morais. Era como se esta transformasse o 
ser humano, num sentido positivo. Conforme suas palavras: "Mas é na verdade singular: ser proprietário, e sobretudo ser proprietário de terra, é uma circunstância que quase modifica favoravelmente as condições morais do homem! " (REBOUÇAS, 1988, p. 125). Conquanto mais de um ponto de ligação possa ser identificado com o pensamento esquerdista, especialmente pela ativa crítica ao monopólio da terra, seus projetos reformistas alimentavam uma forte reciprocidade com o espírito liberal e também com o espírito capitalista. Segundo Rebouças, a aquisição de um pedaço de terra configurava-se como "o limite das aspirações do escravo" (REBOUÇAS, 1988, p. 125).

Do mesmo modo, faz-se interessante destacarmos um pensamento do economista Joseph Garnier, que ele cita em um trecho de seu livro Agricultura Nacional: “O meio mais eficaz e mais enérgico para civilizar os bárbaros ou semibárbaros da Europa, África, América e Ásia, para emancipar os servos e escravos é a construção de sua propriedade individual da terra" (REBOUÇAS, 1988, p. 125).

Somado a isso, podemos observar em suas ideias uma clara influência do evolucionismo social, conforme analisado por Andréa Pessanha. A aquisição de um lote, nesse caso, contribuiria e muito, para a "civilização" dos povos incultos, junto com a extensão da educação. Outro ponto importante é o caráter inclusivo do seu projeto agrário, que beneficiaria tanto os libertos, como os imigrantes e os trabalhadores pobres do campo. Atuante na $\mathrm{SCl}$, Rebouças foi um ardoroso defensor da imigração, mas, ao contrário de muitos dos seus colegas de sociedade como, por exemplo, Louis Couty, não desvalorizava o trabalho dos libertos e dos demais brasileiros pobres.

Um traço bastante forte em seus escritos que pode ser associado ao fato de ser ele mesmo mulato e possivelmente ter enfrentado preconceito durante sua vida. Sua preocupação estava também em garantir um uso racional e produtivo do solo, por isso mesmo criticava veementemente o parasitismo de muitos latifundiários. Sempre se manifestava contra os grandes proprietários que deixavam quantias imensas do solo sem uso produtivo, enquanto que milhares de famílias continuavam na pobreza, desprovidas de qualquer porção de terra para sobrevivência. Esse parasitismo dos latifundiários, que eram por ele comparados com os landlords da Irlanda, configurava-se como grande absurdo por causar um amplo prejuízo para a nação. Rebouças acreditava mais na 
valorização da iniciativa individual e no trabalho. Este último traço, inclusive, ajuda a explicar a sua ideia de que os lotes, quando do parcelamento da terra, não deveriam ser simplesmente doados (PESSANHA, 2005, p. 112).

Ainda nos casos em que previu uma desapropriação como, por exemplo, no caso de terrenos marginais às estradas de ferro, dizia que esses terrenos deveriam ser vendidos, nesse caso, aos imigrantes. Rebouças acreditava que o trabalho e o esforço precisariam ser sempre condições para a obtenção do progresso, conforme essa opinião é que os lotes deveriam ser vendidos ou alugados por um preço justo. Um dos meios de se atingir tal fim seria a adoção do imposto territorial, uma antiga bandeira defendida por diversos parlamentares e tido por Rebouças e pela SCl como um complemento indispensável à abolição. O imposto sendo calculado sobre a superfície acabaria isentando as pequenas propriedades e estimularia, dentro da perspectiva do abolicionista, a subdivisão do solo, uma vez que taxaria as propriedades fundiárias.

Segundo Pessanha, o fato do cálculo do imposto ser baseado na superfície possuída e não em uma renda líquida tinha como premissa viabilizar a cobrança do imposto, pois havia a dificuldade de se avaliar a renda líquida, pois esta passava por variações anuais e de acordo com o tipo de produto explorado. Para se obter tal informação, ficar-se-ia na dependência dos dados repassados pelos proprietários (PESSANHA, 2005, p. 109). Na concepção de Rebouças, a adoção do imposto estimularia também o aperfeiçoamento das culturas, a drenagem e uma série de progressos técnicos para a agricultura. Ademais, ele sempre enfatizou uma preocupação muito forte em relação à agricultura, ressaltando a necessidade de ir além de uma exploração mais justa e racional do solo, mas também de haver maior preocupação com a melhoria e o aumento da produção.

No que se refere à defesa do imposto territorial, Rebouças acreditava que assim que tal medida fosse posta em prática os proprietários acabariam desfazendo-se dos lotes ociosos, pois com isso, não precisariam ter gastos por conta das terras incultas. De acordo com Rebouças, o imposto sobre a renda favorece os ociosos; nada produz; nada paga, ao passo que o imposto sobre a superfície anima os diligentes; quanto mais produz menos paga relativamente; um eterniza a aristocracia, o monopólio e o parasitismo; 
outro desenvolve a democracia rural, promove a subdivisão do solo e anima o talento, a iniciativa e o trabalho. Rebouças, de forma minuciosa, expôs vários detalhes das suas propostas agrárias. A fim de viabilizar logo a cobrança do imposto ele sugeriu, de acordo com Pessanha (2005, p. 111), que se tomasse por base, no caso das terras marginais às estradas de ferro, as plantas utilizadas para a implantação das mesmas; para as demais, deveriam ser considerados os relatórios dos proprietários. Posteriormente, se fixaria uma carta topográfica semelhante à realidade agrária.

No entanto, era de se esperar que, nas décadas de 1870 e 1880 já se houvesse efetuado um levantamento das terras brasileiras, seguindo as disposições da Lei de Terras de 1850. A realidade marcada pela dificuldade de se constituir tal cadastro territorial do Império vinha confirmar um fracasso da Lei de Terras, que como assinalou José Murilo de Carvalho:

(...) ficou longe de atingir todas as propriedades, além de ser pouquíssimo confiável, pela frequente incorreção das declarações. A separação e a demarcação de terras devolutas também ficaram em grande parte sem execução, continuando a ocupação legal. A legitimação e revalidação quase não progrediram, sem sombra de dúvidas, a Lei de Terras não pegou. (CARVALHO, J., 1996, p. 308)

Para Rebouças, a opinião de estimular um parcelamento por vias distintas da simples e "radical" expropriação de terras e posterior distribuição de lotes às famílias, estaria de acordo com as transformações que acredita poderem tomar lugar sem que houvesse grande agitação ou que o latifundiário poderia manter uma parte de sua propriedade e, concomitantemente, algumas áreas poderiam ser vendidas ou alugadas aos trabalhadores rurais. Ao lado disso, manteria em seu centro um engenho ou uma usina de processamento, com a função de recolher produtos como o cacau, o fumo e o algodão, com vistas a prepará-los para a exportação, por meio do emprego de modernas técnicas de beneficiamento do produto. Naquele contexto, não raro encontramos homens como Rebouças, entusiastas do progresso tecnológico e científico. Com esse perfil, Rebouças foi membro da prestigiada Sociedade Auxiliadora da Indústria Nacional 
(SAIN), e através desses contatos era possível conhecer as novidades tecnológicas voltadas para agricultura.

No projeto de Rebouças, "as tradicionais safras de exportação continuariam sendo cultivadas nas propriedades menores" e, após o período de colheita, o produto deveria ser oferecido por um preço justo aos proprietários. Com essa atividade, nesta configuração, os proprietários se transformariam em verdadeiros "industriais rurais". Assim, estando em consonância com o desenvolvimento científico, Rebouças acreditava na viabilidade da agricultura intensiva, que deixaria para trás o modelo extensivo que vinha até aquele momento sendo praticado pelos latifundiários. Para organizar melhor a produção, por exemplo, chamou de "Engenhos Centrais" as unidades onde seriam beneficiadas as colheitas da cafeicultura e de "Fazendas Centrais", aquelas que se encarregariam de lidar com a produção de café (REBOUÇAS, 1988, p. 2).

Dentre tantas propostas e planos, é de se perguntar quantas tentativas obtiveram sucesso, por isso registramos aqui que, nos anos finais do Império, foram estabelecidos alguns desses modelos de engenhos centrais. Contudo, não houve a adoção de todas as premissas colocadas por Rebouças, tendo o seu resultado se distanciando, e muito, da ideia de "democracia rural", sobretudo pela manutenção da exploração da força de trabalho. Rebouças queria que a democracia rural não estivesse vinculada ao governo. Em sua opinião, as autoridades deveriam fomentar e estimular essas transformações propostas, sem intervenção direta e ativa do Estado (REBOUÇAS, 1988, p. 2).

As mudanças na relação de trabalho e na estrutura agrária constituíam, conforme ele defendia, o motor que impulsionaria o desenvolvimento econômico interno. Nessa perspectiva, faz-se igualmente importante conjecturar acerca do significado da reforma agrária de Rebouças e considerar, por exemplo, a suposição desta estar em consonância com uma perspectiva moderada e capitalista. Se analisarmos o programa defendido pela $\mathrm{SCl}$, podemos perceber que de um lado haveria uma perspectiva de reforma tendo em vista, principalmente, o alcance de objetivos econômicos, visando o próprio fortalecimento do capitalismo. Contudo, não podemos negar que naquele mesmo contexto muitos ansiavam por uma reforma mais radical, com elementos socialistas que 
resultassem na transformação do modelo econômico e da realidade social (LIMA, 2015, p. 277).

Nos escritos publicados pela $\mathrm{SCl}$ temos esboçada a ideia de uma reforma que visava promover a justiça social, em que concessões seriam direcionadas às classes marginalizadas, contudo não resultando de fato em uma mudança profunda que provocasse a queda do modelo, que vinha alinhando-se ao capitalismo de produção. Pelo que vimos até aqui, tudo nos indica ser essa a perspectiva de Rebouças. Considerando a articulação com o nascente capitalismo, podemos conceber que esses projetos de reforma de Rebouças mantinham um diálogo com tais ideias.

Essa noção ganha força se atentarmos para o fato de que, entre os modelos socioeconômicos os quais Rebouças trazia aos debates, estava o sistema de colonização desenvolvido nos Estados Unidos naquele final de século XIX, momento em que aquele país apresentava uma ascensão pujante do capitalismo que vinha promovendo a criação de um influente mercado interno e um desenvolvimento industrial, igualmente forte e promissor. Não raro, inclusive em diversos escritos publicados em jornais, Rebouças deixa clara a sua admiração pelo modelo estadunidense:

O liberto e o agregado passarão a ser lavradores com propriedade territorial: a vastíssima região, que hoje é esterilizada por 20.000 fazendeiros, dará riqueza e bem-estar a 3 milhões de libertos e de agregados; nascerá assim a Democracia Rural Brasileira, predestinada a reproduzir no continente Sul-Americano os prodígios, que a Democracia Yankee tem realizado na América do Norte. Ao lado dos 3.000.000 de libertos e agregados se colocarão, todos os anos, 400 a 500.000 imigrantes, como ora acontece na postensa república dos Estados Unidos. (REBOUÇAS, 1880, p.1)

\section{Considerações finais}

Ao observarmos suas posturas e opiniões expressas em planos para o Brasil e, tendo em consideração as atividades capitalistas que desenvolveu, podemos perceber que existiu em Rebouças um intenso posicionamento que se colocava em favor da livre iniciativa como fator impulsionador do progresso econômico de uma nação. Sendo assim, 
mostrou-se contrário às formas de protecionismo e monopólios, especialmente, como vimos, o que denominou de “monopólio da terra". Entre seus estudiosos, alguns destacaram esse seu perfil empresarial, como é o caso de Maria Alice Rezende de Carvalho e Andréa Pessanha. Já Sidney M. G. dos Santos destaca a sua crítica à ação estatal. Além disso, é importante lembrar que o reformismo de Rebouças e da $\mathrm{SCl}$ estavam desvinculados da incipiente indústria da época, o que, segundo Hall (1976, p. 165), devia-se ao fato de que vários líderes do grupo "estavam comprometidos com o comércio estrangeiro".

Mesmo com tais aspectos sendo observados, não podemos afirmar que Rebouças concebesse o social como um aspecto desvinculado da dimensão capitalista. Podemos, com isso, observar na análise sobre a visão do engenheiro, que não se tratava apenas de uma ideologia pró-capitalista. Ao lado disso, autores como Sydney Santos, destacam que Rebouças enfatizava a caridade e o altruísmo, o que descarta a possibilidade de ter tido um perfil preocupado em primeiro lugar com os aspectos econômicos, visto que o social permeia boa parte de seu projeto reformador. Sabemos que Rebouças era um liberal naquele contexto conservador, que inclusive fazia largo uso dos postulados de Adam Smith e François Quesnay, além de apreciar os pensamentos do fisiocrata Turgot (SANTOS, 1985, p. 125).

Lembremos que André Rebouças, e demais nomes ligados a $\mathrm{SCl}$, como Alfredo Taunay e outros, escreveram em um contexto nacional ainda marcado pela manutenção de estruturas coloniais arcaicas, das quais a escravidão representava o principal aspecto. O liberalismo, dentro desse quadro, não necessariamente possuía a conotação que veio a ter posteriormente, de sistema eminentemente preocupado com o florescimento do capitalismo e com o pouco interesse acordado às questões sociais. Acreditamos que essas considerações possibilitam apreender as propostas sociais da $\mathrm{SCl}$, e também a reforma agrária, dentro de uma lógica em que o seu liberalismo, por mais articulado que estivesse com o capitalismo ascendente, incluía uma preocupação social sincera e forte.

Rebouças afirmou, e a SCl endossava fortemente, que "a Democracia Rural é o mais forte tronco da Democracia Nacional. Em suas palavras, "A Democracia Rural é a aspiração secular da escola liberal” (REBOUÇAS, 1988, p. 306). Percebe-se claramente 
que tanto Rebouças como a $\mathrm{SCl}$ associavam diretamente a ideia de propriedade à de democracia e de liberdade. O acesso à propriedade rural por uma ampla parcela da população era visto, nessa ótica, como fator essencial de progresso de uma nação, sendo mesmo condição de afirmação da própria democracia.

Para além da democratização do espaço rural, José Augusto Pádua (2002), considerando a atuação dos teóricos da crítica ambiental no período monárquico, inseriu em suas análises o pensamento e a visão de Rebouças, especialmente a sua defesa de que a ideia de reforma agrária levaria a uma transformação da agricultura. Rebouças via nesse caminho a possibilidade de as atividades agrícolas abandonarem sua forma predatória e, consequentemente, a degradação do ambiente.

Portanto, temos presente, mesmo que em pequena escala, a preocupação com os aspectos ambientais, que vêm sendo amplamente discutidos em nossos dias. A preocupação ambiental de Rebouças adquire destaque especialmente no que diz respeito ao melhor aproveitamento dos recursos oriundos das próprias atividades agropecuárias (como uso de estrumes, ideias de compostagem e etc.). Por fim, ao entrarmos em contato, brevemente, com as propostas agrárias desenvolvidas por Rebouças, nos é possível detectar a influência de uma ideologia liberal capitalista. Todavia, em contrapartida, está presente em suas propostas uma preocupação com o social, talvez resultante de uma identificação com aqueles cuja lógica econômica permanecia, em grande medida, excluindo.

O desfecho de sua trajetória é considerado um tanto trágico; Rebouças acompanhara o imperador no exílio e estava firmemente convencido de que a república havia sido um golpe produzido pelos ressentimentos das antigas oligarquias escravocratas, especialmente por seu temor de verem implementadas reformas que levassem à "democracia rural”, que - do seu ponto de vista - deveria golpear o latifúndio e complementar a obra da abolição. Não há dúvidas da depressão que o acompanhou em seus últimos anos de vida. A forma como foi vivida, porém - como aguda consciência de suas origens africanas -, ilumina muito além das dificuldades pessoais por ele enfrentadas. Após sua mudança para o exterior, ainda publicou alguns artigos na imprensa do Rio de Janeiro. Permaneceu um tempo em Portugal e depois passou a residir 
em Funchal, na Ilha da Madeira, onde veio a falecer, em 1898. Sua morte causou grande comoção entre seus parceiros de luta.

\section{Referências bibliográficas}

CARVALHO, José Murilo de. A construção da ordem: a elite política imperial. Rio de Janeiro: Ed. UFRJ, 1996.

CARVALHO, Maria Alice Rezende de. 0 quinto século: André Rebouças e a construção do Brasil. Rio de Janeiro: Revan: IUPERJ/UCAM, 1998.

HALL, Michel. Reformadores de classe média no império brasileiro: a sociedade central de imigração. In: Revista de História, São Paulo: Universidade de São Paulo: n. 107, 1976. Pp. 147-171.

JUCÁ, Joselice. Estudo Introdutório. In: REBOUÇAS, André. Agricultura nacional e estudos econômicos: propaganda abolicionista e democrática. Recife: Fundação Joaquim Nabuco, 1988.

JUCÁ, Joselice. André Rebouças - reforma \& utopia no contexto do segundo império: quem possui a terra possui o homem. Rio de Janeiro: Odebrecht, 2001.

LIMA, Angela B. "Nós declaramos guerra ao latifúndio": propostas, ações e ideais de imigração/colonização da Sociedade Central de Imigração (1883-1891). 2015. Dissertação (Mestrado em História) - Universidade Federal de Santa Catarina, Florianópolis, 2015.

PÁDUA, José Augusto. “Um sopro de destruição”: pensamento político e crítica ambiental no Brasil Escravista, 1786 - 1888. Rio de Janeiro: Jorge Zahar, 2002.

PESSANHA, Andréa Santos. Da abolição da escravatura à abolição da miséria: a vida e as ideias de André Rebouças. Rio de Janeiro: Quartet; Belford Roxo: UNIABEU, 2005.

REBOUÇAS, André. Agricultura nacional e estudos econômicos: propaganda abolicionista e democrática. Recife: Fundação Joaquim Nabuco, 1988.

REBOUÇAS, André. Latifundios. Gazeta da Tarde, Rio de Janeiro, anno 1, n 124, 01 de dez. de 1880 .

SANTOS, Sidney M.G. dos. André Rebouças e seu tempo. Rio de Janeiro, 1985. 
UBINATI, Inoã Pierre C. Ideias e projetos de reforma agrária no final do Império (18711889): uma análise de seu sentido político e social. 2008. Dissertação (Mestrado em História). Universidade do Estado do Rio de Janeiro, Rio de Janeiro, 2008.

Universidade do Estado de Santa Catarina - UDESC

Centro de Ciências Humanas e da Educação - FAED

Revista PerCursos

Volume 20 - Número 43 - Ano 2019 revistapercursos@gmail.com 